\title{
Assessing Equity in Bulgarian Health System
}

\author{
Assoc. Prof. PhD Maria Rohova \\ Medical University - Varna, Varna, Bulgaria \\ mariarohova@abv.bg
}

\begin{abstract}
The aim of the study is to assess the equity in Bulgarian health system based on a set of interrelated indicators. The most common equity indicators used for health system performance assessment are explored, and a set of several reliable and available indicators is constructed. Indicators related to health status and health outcomes, access to health services, health system financing and financial protection of the population and quality of health services are selected. The selected indicators are analysed by separate population groups, and the results of the analysis and assessment show that the equity in the health system in Bulgaria is disturbed and severe inequalities between different socio-economic groups are identified.
\end{abstract}

Keywords: equity, health system, self-perceived health, unmet needs, health expenditures

JEL Code: I14; doi:10.36997/IJUSV-ESS/2019.8.1.36

\section{Въведение}

Равнопоставеността в здравеопазването е една от общите ценности на странитечленки на Европейския съюз (ЕС) и един от основополагащите принципи на здравните им системи. В изявление на Съвета на ЕС относно общите ценности и принципи на здравните системи тя е дефинирана като „равен достьл, който зависи от потребностите, без значение от етнос, пол, възраст, сочиилен статус и икономически възможности“ (Council of the EU, 2006). Много правителства декларират политически ангажимент към осигуряване на равнопоставеност в здравната система, поради което степента, в която това е постигнато, е важен измерител при оценката на функционирането на самата система.

Равнопоставеността присъства като ключово измерение в повечето концептуални рамки за оценка на функционирането на здравната система, както в предложените от Световната здравна организация (С3О) и Организацията за икономическо сьтрудничество и развитие (ОИСР) (Arah et al., 2006; Murray \& Frenk, 2000), така и в редица национални рамки като тези на Белгия, Холандия, Великобритания, Португалия, Австралия, Канада, Нова Зеландия (Devos et al., 2019; National Institute for Public Health and Environment, 2015; Department of Health, 2013; WHO Europe, 2010; Australian Institute of Health and Welfare, 2018; Canadian Institute for Health Information, 2013; Gauld et al., 2011) и др. Но при измерването на равнопоставеността се срещат редица методологически проблеми, свързани с различните интерпретации на тази сложна категория.

В съвременната литература се обсъждат редица дефиниции на равнопоставеността, като G. Mooney идентифицира седем, които са свързани с предоставянето на здравни услуги (Mooney, 1983). Равенство в достьпа до здравни услуги, равенство при използването на здравни услуги при еднакви потребности и равенство в здравните резултати (в здравния статус) между регионите и/или социалните групи са най-често дискутираните интерпретации, включително и при измерване на постигнатите резултати или на неравнопоставеността в здравната система. Освен с предоставянето на здравни услуги, равнопоставеността в здравеопазването се дефинира често и от гледна точка на финансирането, при което разходите за здравеопазване на индивидите и домакинствата трябва да зависят от възможностите за заплащане и поради това трябва да бъдат пропорционални на дохода. Съгласно тази интерпретация хората с по-високи доходи би трябвало да плащат повече и обратно - тези с пониски доходи трябва да заплащат по-малко, независимо от рисковете за здравето им или използването на медицинска помощ. В. Whitehead добавя към равенството в достьпа и използването на здравни услуги и еднакво качество за всички (Whitehead, 1991), което 
означава, че всички получават услугите, които са им нужни, с едни и същи професионални стандарти, включително и времето за консултация. В концептуалната рамка за оценка на функционирането на здравните системи на СЗО от 2000 г. се използва още една интерпретация - равнопоставеност при посрещане на очакванията на пациентите, които не са свързани директно с медицинската помощ (responsiveness), като зачитане на достойнството на пациентите, възможностите им за избор, комуникациите с медицинските специалисти, условията на престой в лечебните заведения и др. (Murray \& Frenk, 2000).

Поради различните интерпретации на равнопоставеността в здравеопазването в отделните концептуални рамки, конструирани за оценка на функционирането на здравната система, се използват множество показатели за нейното измерване и оценка. Предизвикателство е да се отсеят онези от тях, които са надеждни измерители и дават достоверна представа за състоянието и развитието на здравната система в тази връзка. Освен това важен аспект при анализа и оценката на равнопоставеността е стратификацията на населението в определени групи и сравняване на постигнатите резултати за всяка от тях. Най-често се използват различни социално-икономически признаци за определяне на групите като доход, образователно равнище, местоживеене, но могат да бъдат използвани и разделения по пол, възраст, здравословно състояние и др.

Целта на настоящето изследване е да се направи оценка на равнопоставеността в здравната система в България въз основа на комплекс от взаимосвързани показатели.

\section{1. Материали и методи}

Във връзка с целта на изследването са проучени показателите, които се срещат найчесто при оценка на функционирането на здравните системи в различни държави, както и такива, които се препорьчват в методически ръководства на международни организации или в научни публикации по темата. За идентифициране на релевантните показатели са използвани 31 източници, от които 18 национални концептуални рамки за оценка на функционирането на здравната система със съответните показатели и еволюцията им през различните години, осем доклада на международни организации като С3О, ОИСР и др., както и пет научни изследвания на отделни автори, свързани с темата. От посочените източници са идентифицирани общо 359 показатели, които се използват или са предложени за измерване на равнопоставеността при оценка на функционирането на здравната система. Дублиращите се показатели, както и тези, които са много близки по значение, са редуцирани, като в резултат от това показателите са сведени до 157, които са обобщени в няколко групи, съответстващи на интерпретациите за равнопоставеност.

От идентифицираните показатели са подбрани онези, които са надеждни измерители на равнопоставеността и в същото време за тях са налични данни, необходими за осъществяване на оценката за България. Използваните показатели са свързани със здравния статус и здравните резултати, достъпа до здравни услуги, финансирането на здравната система и финансовата защита на населението, качеството на здравните услуги. Те са анализирани по отделени групи от населението, стратификацията на които може да даде представа за равнопоставеността (или несправедливите неравенства) в здравната система в България. Използваните материали включват данни от електронните бази на Евростат и Националния статистически институт, статистически справочници, научни публикации и доклади на международни организации.

\section{2. Резултати и обсъждане}

За оценка на равнопоставеността в здравната система в България са използвани 11 показателя, обобщени в четири основни групи:

- здравен статус и здравни резултати - самооценка на здравето по подоходни групи, образователно равнище и тип на населеното място; наличие на продължително (хронично) заболяване или здравен проблем по подоходни групи, образователно 
равнище и тип на населеното място; очаквана продължителност на живота спрямо образователното равнище;

- достъп до здравни услуги - неудовлетворени потребности от медицинска помощ и неудовлетворени потребности от дентална помощ по тип населено място, подоходни групи и образователно равнище; население на един лекар и население на един лекар по дентална медицина по области;

- качество на здравните услуги - смъртност, която може да бъде избегната с промоция и профилактика, по пол и предотвратима смъртност по пол;

- финансиране на здравната система и финансова защита на населението - разходи за здравеопазване като дял от общите разходи на домакинствата по подоходни групи и катастрофални здравни разходи.

Здравен статус и здравни резултати

Едни от често срещаните показатели за оценка на здравния статус и здравните резултати са тези, свързани със самооценката на здравето и наличието на продължително заболяване или здравен проблем, които ограничават възможността за извършване на обичайни ежедневни дейности. Информация за тези показатели се набира при провеждането на Европейското здравно интервю. Респондентите оценяват собственото си здраве по петстепенна скала - „много добро“, „добро“, „задоволително“, „,ошо“ и „много лошо“.

През последните години показателите за България като цяло се подобряват, намалява броят на хората, които оценяват здравето си като „лошо“ и „много лошо“ и се увеличава дельт на онези, които смятат, че здравословното им състояние е „много добро“ или „добро“. Но все още по отношение на самооценката на здравето страната ни изостава от средните стойности за ЕС, докато по показателя „наличие на продължително заболяване или здравен проблем“ стойностите за България са по-добри от средните за Съюза (Фигура 1).

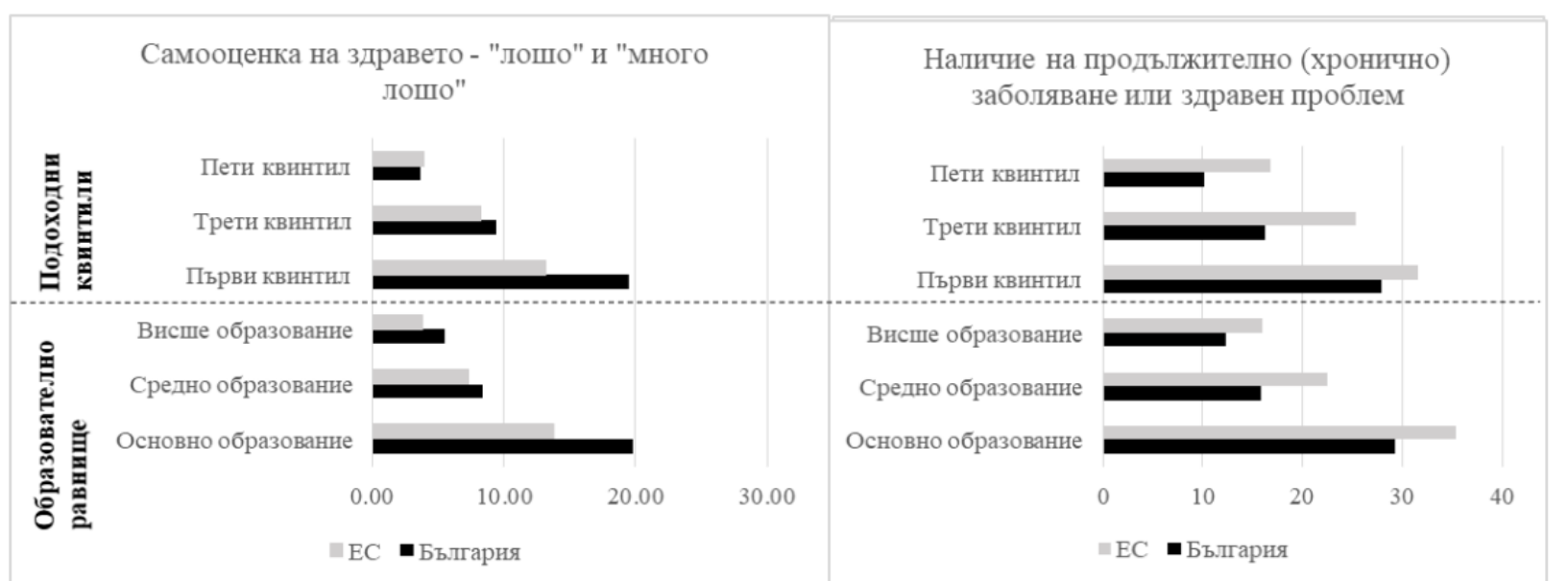

Източник: Eurostat, 2019.

Фигура 1. Самооценка на здравето и наличие на здравен проблем по подоходни групи и образователно равнище в България и ЕС, 2017 г. (в \%)

Въпреки че като цяло показателите се подобряват, разгледани като различия между отделните групи от населението, се установява наличието на съществени неравенства. Значителни разлики се наблюдават между първи и пети подоходен квинтил (групите с найниски и най-високи доходи от населението), като и между хората с основно и тези с висше образование (Фигура 1 и Таблица 1). Тези разлики в България са по-големи от средните за $\mathrm{EC}$, което показва, че социално-икономическите детерминанти на здравето у нас оказват посилно негативно влияние върху здравословното състояние на по-уязвимите социални групи. Подоходните неравенства и тези спрямо образователното равнище са свързани до известна степен, доколкото по-високото образователно равнище обикновено предполага и наличието на по-високи доходи. 
Различията при самооценката на здравето и наличието на здравен проблем са наймалки както в абсолютни, така и в относителни стойности между градовете и селата. При показателя „самооценка на здравето“ абсолютните разлики между подоходните групи и групите по образователно равнище през 2017 г. намаляват спрямо тези, установени за 2011 г., но в същото време относителните разлики се увеличават. Това показва, че здравословното състояние на хората с по-високи доходи и по-високо образование се подобрява по-бързо от това на групите с ниски доходи и основно образование. При показателя „наличие на продължително заболяване или здравен проблем“ се наблюдава обратното - абсолютните различия нарастват през 2017 г., а относителните намаляват (Таблица 1). Но и в двата случая се установяват съществени социално-икономически здравни неравенства.

Таблица 1. Различия при самооценка на здравето и наличие на здравен проблем по подоходни групи, образователно равнище и тип на населеното място в България

\begin{tabular}{|c|c|c|c|c|c|c|c|c|}
\hline \multirow{3}{*}{$\begin{array}{l}\text { Разлики } \\
\text { групи }\end{array}$} & \multicolumn{4}{|c|}{$\begin{array}{c}\text { Самооценка на здравето - } \\
\text { „лошо“ и „много лошо“ }\end{array}$} & \multicolumn{4}{|c|}{$\begin{array}{c}\text { Наличие на продължително } \\
\text { заболяване или здравен проблем }\end{array}$} \\
\hline & \multicolumn{2}{|c|}{2010} & \multicolumn{2}{|c|}{2017} & \multicolumn{2}{|c|}{2010} & \multicolumn{2}{|c|}{2017} \\
\hline & $\Delta$ & $R R$ & $\Delta$ & $R R$ & $\Delta$ & $R R$ & $\Delta$ & $R R$ \\
\hline $\begin{array}{l}\text { Първи-пети } \\
\text { квинтил }\end{array}$ & 17,6 & 5,1 & 15,9 & 5,4 & 16,2 & 3,3 & 17,8 & 2,8 \\
\hline $\begin{array}{l}\text { Основно-висше } \\
\text { образование }\end{array}$ & 17,6 & 4,6 & 14,3 & 3,6 & 15,2 & 2,6 & 16,9 & 2,37 \\
\hline Село-град & 5,4 & 1,6 & 7,5 & 1,9 & 5,1 & 1,4 & 8,4 & 1,5 \\
\hline
\end{tabular}

Забележка: $\Delta$ - абсолютна разлика; RR - относителна разлика. Източник: Изчисленията са на автора по данни на Eurostat, 2019.

Друг често използван показател за здравословното състояние е очакваната продължителност на живота, измервана в години предстоящ живот. За България се събират данни, стратифицирани само според образователното равнище. От фигура 2 може да се проследи, че различията между групите с висше и основно образование намаляват от 11,4 години през 2010 г. до 6,7 години през 2017 г. Това обаче се случва не само благодарение на повишената продължителност на живота при хората с основно образование, а и поради намаляването на очакваната продължителност на живота при хората с висше образование. Такава тенденция не се наблюдава в други страни на ЕС.

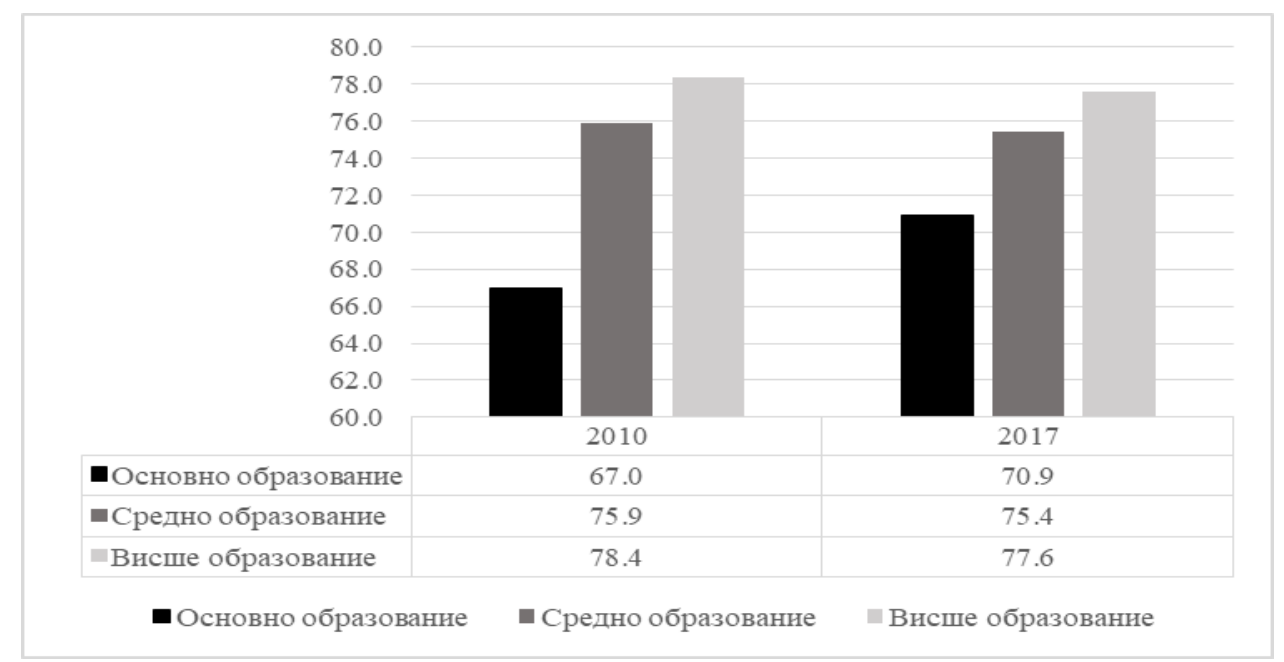

Източник: Eurostat, 2019.

Фигура 2. Очаквана продължителност на живота по образователно равнище в България (в години) 
Достъп до здравни услуги

Информация за показателите „неудовлетворени потребности от медицинска или дентална помощ“ също се събира с Европейското здравно интервю, като се проучват и причините, поради които респондентите декларират, че не са получили нужната им помощ. Обикновено тези причини се отнасят до разходите на индивидите и домакинствата, свързани със самото използване на здравната услуга (директно заплащане или доплащане за услугата), транспортните разходи или отдалечеността на изпълнителя на услугата, както и дългото време за чакане. Тези причини се възприемат и като ограничения в достъпа до здравни услуги и са предпоставки за възникване или задълбочаване на неравенствата.

През последните години дельт на хората, които декларират, че имат неудовлетворени потребности от медицинска помощ намалява съществено - от 10,3\% през 2010 г. до 2,1\% през 2017 г. (Eurostat, 2019). Отново обаче остават значителни различия между отделните социално-икономически групи от населението. По-уязвимите групи като хората с най-ниски доходи, тези с основно образование и живеещите в селата в България в много по-голяма степен считат, че потребностите им от медицинска помощ са неудовлетворени и стойността на показателя при тях значително надхвърля средните стойности за ЕС (Фигура 3). В същото време групите с по-високи доходи и по-високо образование, както и тези, живеещи в градовете, регистрират стойности по-ниски от средните за Съюза. В следствие на това „ножицата“ на различията в нашата страна е значително по-разтворена и неравенствата, наблюдавани в България, са два пъти по-големи от тези в ЕС.

Като най-честа причина за неудовлетворените потребности от медицинска помощ се посочват разходите, които потребителите трябва да направят, за да я получат, а нейното значение се засилва с намаляване на доходите. Отдалечеността от лечебно заведение, свързана с необходимостта от пътуване, както и времето за чакане имат значително по-малко влияние в България, като при времето за чакане стойностите на показателя са доста под средните за EC (Eurostat, 2019). Или основният проблем в нашата страна са т.нар. частни разходи или разходите, които индивидите и домакинствата отделят за здравни услуги.

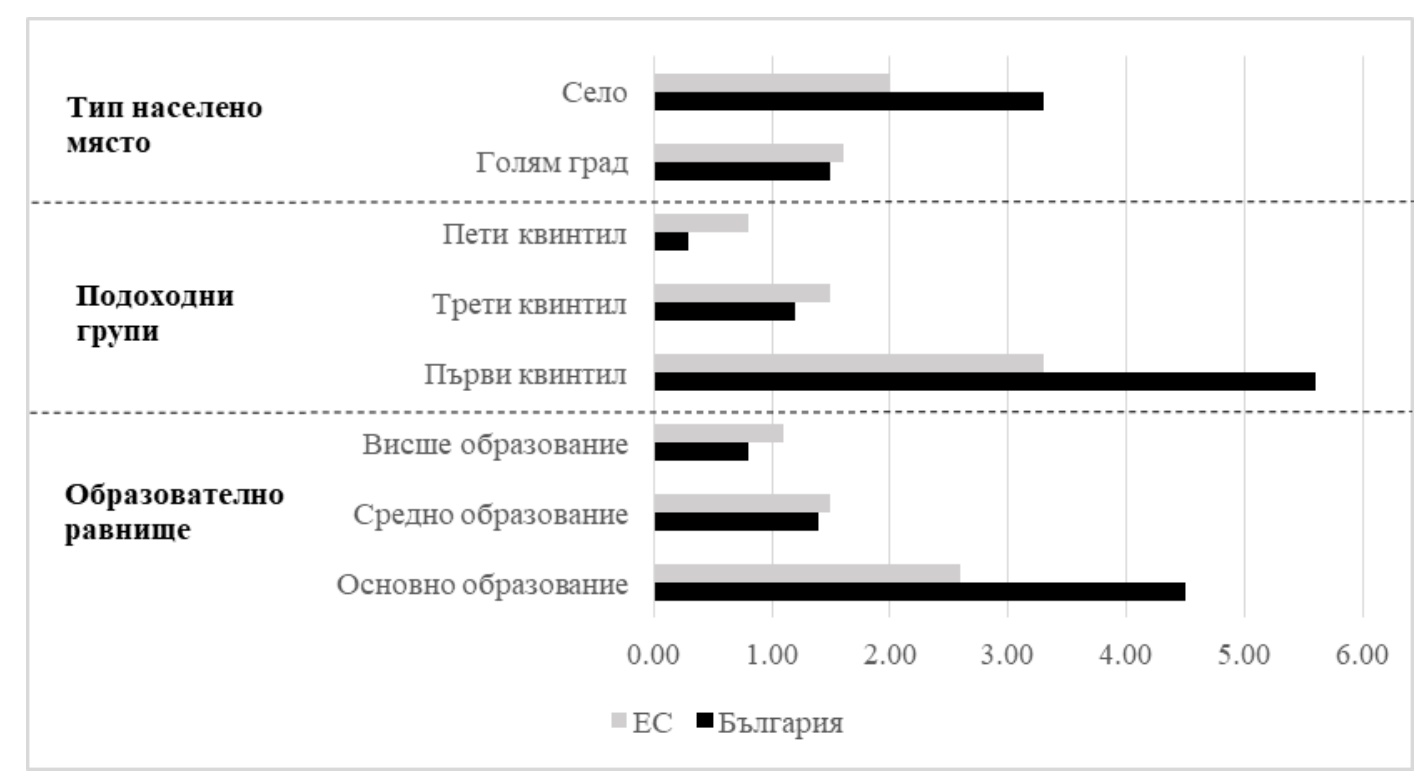

Източник: Eurostat, 2019.

Фигура 3. Неудовлетворени потребности от медицинска помощ по тип населено място, подоходни групи и образователно равнище, 2017 г.

Различията между социално-икономическите групи по отношение на неудовлетворените потребности от медицинска помощ в България намаляват като абсолютни стойности през 2017 г. спрямо 2010 г., но относителната разлика нараства (Таблица 2). 
Причината отново е по-бързият темп, с който се снижава делът на хората с по-високи доходи или образователно равнище, деклариращи неудовлетворени потребности, в сравнение с този на групите с по-ниски доходи или образование. Това от своя страна води до задълбочаване на неравенствата между тези групи.

Таблица 2. Различия при неудовлетворените потребности от медицинска помощ по подоходни групи, образователно равнище и тип на населеното място в България

\begin{tabular}{|l|c|c|c|c|}
\hline \multirow{2}{*}{ Разлики по групи } & \multicolumn{2}{|c|}{$\mathbf{2 0 1 0}$} & \multicolumn{2}{c|}{$\mathbf{2 0 1 7}$} \\
\cline { 2 - 5 } & $\Delta$ & $R R$ & $\Delta$ & $R R$ \\
\hline Пьрви-пети квинтил & 18,7 & 5,3 & 5,3 & 18,7 \\
\hline $\begin{array}{l}\text { Основно-висше } \\
\text { образование }\end{array}$ & 13,2 & 4,1 & 3,7 & 5,6 \\
\hline Село-град & 2,8 & 1,3 & 1,8 & 2,2 \\
\hline
\end{tabular}

Забележка: $\Delta$ - абсолютна разлика; $\mathrm{RR}$ - относителна разлика. Източник: Изчисленията са на автора по данни на Eurostat, 2019.

За разлика от медицинската помощ, дельт на хората, деклариращи неудовлетворени потребности от дентална помощ в България, е по-нисък от този в ЕС като цяло (Фигура 4). Това се отнася и за отделните подоходни групи. Разликата между най-бедните и найбогатите в нашата страна, обаче, е по-голяма от тази в Европа. Отново основната причина за неудовлетворените потребности са разходите за дентални услуги. Това е и очаквано предвид факта, че само някои услуги се покриват частично от Националната здравноосигурителна каса и при това с определено ограничение на техния годишен брой.

През последните години абсолютните разлики в България намаляват, но относителните се увеличават неколкократно спрямо 2010 г. Същото се наблюдава и в ЕС, но със значително по-малки разлики (Eurostat, 2019).

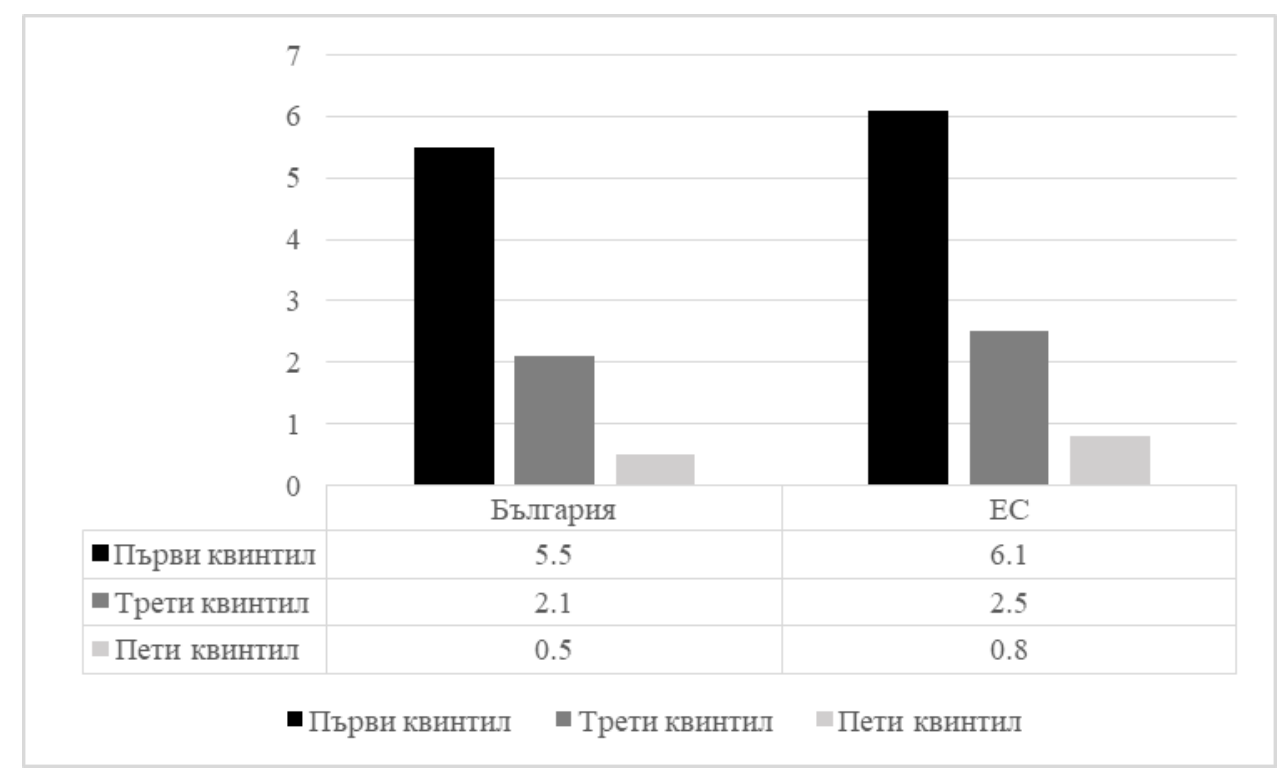

Източник: Eurostat, 2019.

Фигура 4. Неудовлетворени потребности от дентална помощ по подоходни групи, 2017 г.

Във връзка с достъпа до здравни услуги важно значение има осигуреността с медицински специалисти в различните региони и населени места на страната, която има пряко отношение към възможността на пациентите да ползват необходимите им здравни услуги. В България се наблюдават дисбаланси между отделните региони по отношение на 
осигуреността с лекари, като тези различия стават значителни, когато се разглеждат по области и разпределението на лекарите по различни специалности между тях (Rohova, 2017).

На фигури 5 и 6 са представени данни за броя на населението, падащо се на един лекар и респ. на един лекар по дентална медицина по области на страната през 2018 г. От данните се вижда съществено разминаване на стойностите на показателя в някои области спрямо средните стойности за България. Стойностите на показателя в областите с най-висока осигуреност са близо 2,4 пъти по-големи от тези в областите с най-ниска осигуреност с лекари (Фигура 5). При лекарите по дентална медицина това съотношение е близо 3 пъти (Фигура 6). Различията в осигуреността с лекари се свързват и с декларираните неудовлетворени потребности от медицинска и от дентална помощ, особено при населението на селските райони, където се наблюдава значителен недостиг предимно на общопрактикуващи лекари.

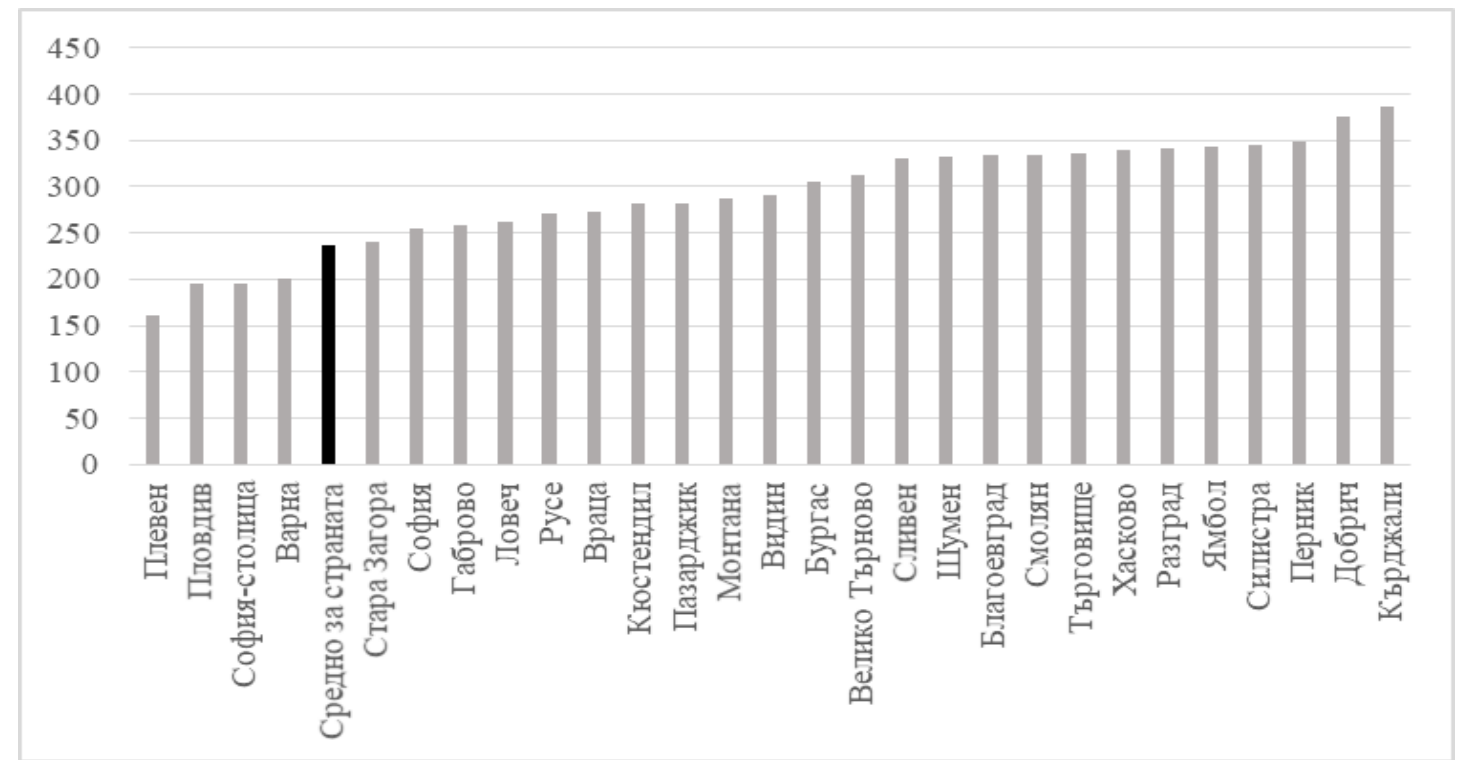

Фигура 5. Население на един лекар по области, 2018 г.

Източник: NSI, 2019.

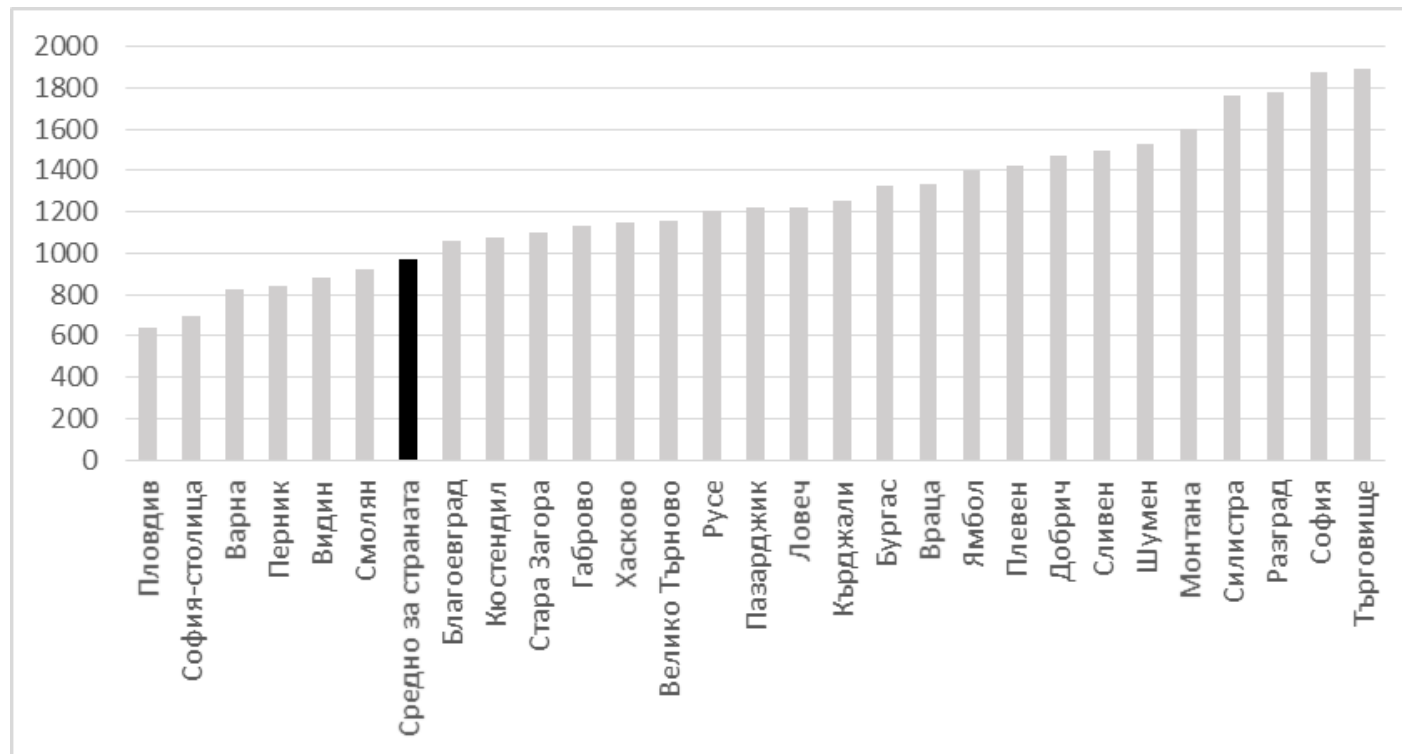

Източник: NSI, 2019.

Фигура 6. Население на един лекар по дентална медицина по области, 2018 г. 
Качество на здравните услуги

Смъртността е един от водещите индикатори, които се използват за оценка на здравословното състояние на населението. Тя често се разделя на преждевременна (преди определена възраст - обикновено 75 години) и непреждевременна (Gay et al., 2011). Екип от Харвардския университет разработва концепцията за смъртност, която може да бъде избегната (avoidable mortality), използвана като показател за качеството на медицинската помощ в здравната система, част от преждевременната смъртност (Rutstein et al, 1976). В разработките на екипа тази смъртност е дефинирана като „смъртни случаи от определени заболявания, които могат да бъдат избегнати с лечение или превенция“. Смъртността, която може да бъде избегната, се разделя от своя страна на две големи групи - смъртност, която може да бъде избегната с дейности, свързани с опазване на общественото здраве като профилактика и промоция на здравето (preventable mortality), и т.нар. предотвратима смъртност - от заболявания, които могат да бъдат излекувани (amenable/treatable mortality) (Newey et al., 2004). Има разработени списъци със заболявания, които се смятат за лечими при използване на последните достижения на медицинската наука преди определена възраст (Nolte \& McKee, 2008; Tobias \& Yeh, 2009).

Смъртността, която може да бъде избегната с помощта на дейности от общественото здравеопазване или с лечение, в България е значително по-висока от тази в ЕС както при мъжете, така и при жените (Таблица 3). Освен това през последните години тя нараства, с изключение на предотвратимата смъртност при жените, за разлика от тази в Съюза. Този факт свидетелства и за влошаване на качеството на здравните услуги в страната.

Обичайно е продължителността на живота при мъжете да е по-ниска от тази при жените, което е пример за неравенство, но не и за неравнопоставеност, тъй като е обусловено от генетични, а не от социално-икономически фактори. Поради това смъртността, която може да бъде избегната, при мъжете е по-висока от тази при жените, но различията между двата пола по тези показатели в България са значително по-големи от средните разлики в ЕС. Това показва, че освен биологично обусловените неравенства влияние оказват и други фактори, които можем да свържем с несправедливи различия в здравословното състояние пример за неравнопоставеност в здравеопазването.

Таблица 3. Смъртност, която може да бъде избегната, в България и ЕС, на 100000 души

\begin{tabular}{|l|c|c|c|c|}
\hline \multirow{2}{*}{} & \multicolumn{2}{|c|}{ Мъже } & \multicolumn{2}{c|}{ Жени } \\
\cline { 2 - 5 } & $\mathbf{2 0 1 1}$ & $\mathbf{2 0 1 7}$ & $\mathbf{2 0 1 1}$ & $\mathbf{2 0 1 7}$ \\
\cline { 2 - 5 } & \multicolumn{2}{|c}{ Смътност, която може да бъде избегната с промоиия и профилактика } \\
\hline България & 344,63 & 363,15 & 119,32 & 120,18 \\
\hline ЕС & 262,09 & 237,75 & 96,01 & 91,33 \\
\hline & Предотвратима смъртност (смъртност, която може да бъде избегната с подходящо лечение) \\
\hline България & 248,09 & 251,86 & 151,54 & 87,72 \\
\hline ЕС & 120,37 & 107,38 & 146,26 & 79,60 \\
\hline
\end{tabular}

Източник: Eurostat, 2019.

Финансиране на здравната система и финансова защита на населението

От гледна точка на финансирането равнопоставеността се фокусира върху въпроса „колко справедливо е то съобразно платежоспособността на населението“. Това оказва директно въздействие върху достъпа, тъй като финансовите бариери възникват от системата за финансиране. Справедливото финансиране е свързано със защитата на населението от т.нар. катастрофални здравни разходи - това са такива разходи за здравеопазване, които поставят домакинството под линията на бедността. В различни изследвания делът на частните разходи за здравеопазване, които се определят като катастрофални, от общите разходи на домакинството варира между 5 и 20\% (Wyszewianski, 1986; Berki, 1986). Според 
СЗО здравните разходи, които са над 40\% от разходите на домакинството, приспадайки тези за храна, могат да се определят за катастрофални (WHO, 2001).

Изследванията върху катастрофалните разходи за здравеопазване на домакинствата не са регулярни в България. През 2000 г. анализ на тези разходи в различни държави показва, че домакинствата, изпаднали в бедност поради здравни разходи, в нашата страна са около $2 \%$ $(1,77-2,23 \%)$, като подобни стойности са високи за Европа (Xu et al., 2003). Сходни данни представя С3О за периода 2002-2012 г., като за България малко над 2\% от домакинствата изпитват катастрофални здравни разходи (WHO, 2016). За периода 2006-2015 г. 13\% от домакинствата в България са изразходвали $10 \%$ от бюджета си за здравеопазване, а при 0,8\% от домакинствата дельт на тези разходи достига $25 \%$, които могат да се определят като катастрофални (Wagstaff et al., 2018).

Разгледани по подоходни групи, относителната тежест на здравните разходи в бюджета на домакинствата в България варира чувствително - от 3,5 до 8,4\% през 2018 г. (Фигура 7). Тя нараства постепенно с увеличаване на доходите на домакинствата и достига най-високата си стойност в четвъртата децилна група. Можем да твърдим, че най-голяма е тежестта на разходите за здравеопазване за хората с ниски и средни доходи, като при найбогатите домакинства тя значително намалява и е под средната стойност от $5,5 \%$ за страната през 2018 г. Това подкрепя извода, че финансовата защита на населението е слаба и се наблюдават съществени неравенства от гледна точка на частните разходи за здравеопазване, което от своя страна е предпоставка за задълбочаване на неравенствата в достъпа до здравни услуги.

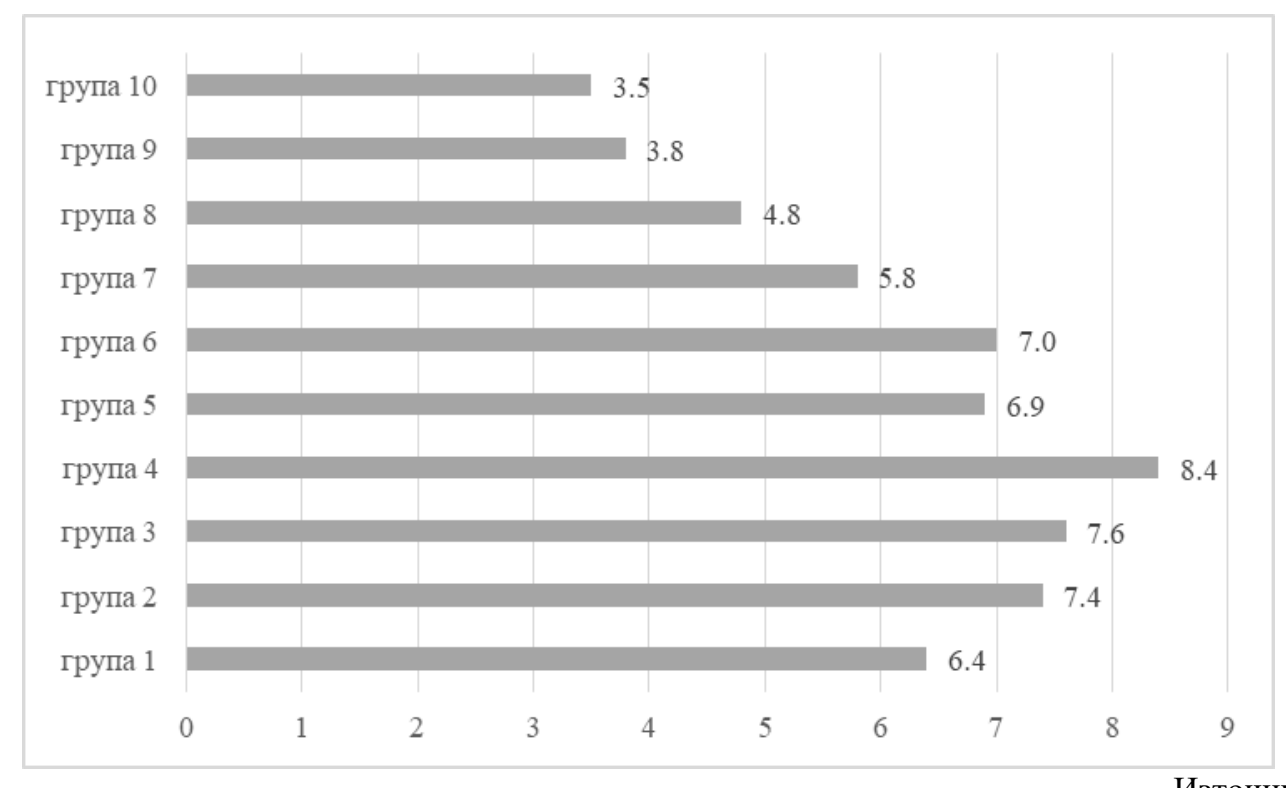

Фигура 7. Разходи за здравеопазване като дял от общите разходи на

Източник: NSI, 2019. домакинствата по децилни подоходни групи, 2018 г.

\section{Заключение}

Оценката на равнопоставеността в здравната система е амбициозно начинание, като основното предизвикателство е да се определят най-подходящите показатели за целта. Те трябва да дават ясна и надеждна картина за онези неравенства, които може да се определят като несправедливи и нечестни, т.е. за примери за неравнопоставеност в здравеопазването.

Резултатите показват, че равнопоставеността в здравната система в България е нарушена и съществуват редица неравенства между отделни социално-икономически групи, въпреки че някои от тях намаляват през последните години. Наличието на неравенства, 
особено такива, свързани с достъпа до здравни услуги и разходите на домакинствата за здравеопазване, разкриват сериозни проблеми във функционирането на здравната система, които е необходимо да бъдат преодолени с подходящи политики. Това от своя страна би спомогнало да намалеят и различията в здравните резултати (здравословното състояние) на населението.

\section{References}

1. Arah, O.A., Westert, G.P., Hurst, J. and Klazinga, N.S. (2006) A conceptual framework for the OECD Health Care Quality Indicators Project. International Journal of Quality in Health Care. 18 (Suppl 1). pp. 5-13.

2. Australian Institute of Health and Welfare (2018) Australia's health 2018. Australia's health series no. 16. Canberra: Australian Institute of Health and Welfare. [Online] Available from: https://www.aihw.gov.au/getmedia/7c42913d-295f-4bc9-9c24-4e44eff4a04a/aihw-aus221.pdf.aspx ?inline $=$ true [Accessed 28/08/2019].

3. Berki, S.E. (1986) A look at catastrophic medical expenses and the poor. Health Affairs. 5 (4). pp. 139-145.

4. Canadian Institute for Health Information (2013) Health indicators 2013. Ottawa: Canadian Institute for Health Information. [Online] Available from: https://secure.cihi.ca/free_products/HI2013_EN.pdf [Accessed 18/08/2019].

5. Council of the European Union (2006) Council Conclusions on Common values and principles in European Union health systems. Official Journal of European Union. 49 (C 146). pp. 1-3.

6. Department of Health (2012) The NHS outcomes framework 2013/14. London: Department of Health. [Online] Available from:

https://assets.publishing.service.gov.uk/government/uploads/system/uploads/attachment_data/fi le/213055/121109-NHS-Outcomes-Framework-2013-14.pdf [Accessed 18/08/2019].

7. Devos, C., Cordon, A., Lefèvre, M., Obyn, C., Renard, F., Bouckaert, N. et al. (2019) Performance of the Belgian health system - report 2019. Health Services Research (HSR) Brussels: Belgian Health Care Knowledge Centre. KCE Reports 313. D/2019/10.273/34. [Online] Available from:

https://kce.fgov.be/sites/default/files/atoms/files/KCE_313C_Performance_Belgian_health_syst em_Report.pdf [Accessed 20/08/2019].

8. Eurostat. Database (2019) [Online] Available from: https://ec.europa.eu/eurostat [Accessed 1418/09/2019].

9. Gauld, R., Al-Wahaibi, S., Chisholm, J., Crabbe, R., Kwon, B., Oh, T., et al. (2011) Scorecards for health system performance assessment: The New Zealand example. Health Policy. 103 (23). pp. 200-8.

10. Gay, J.G., Paris, V., Devaux, M. and de Looper, M. (2011) Mortality amenable to health care in 31 OECD countries: Estimates and methodological issues. OECD Health Working Papers, No. 55. Paris: OECD Publishing.

11. Mooney, G. (1983) Equity in health care: confronting the confusion. Effective Health Care. 1 (4). pp. 179-185.

12. Murray, C. and Frenk, J. (2000) A framework for assessing the performance of health systems. Bulletin of the World Health Organisation. 78 (6). pp. 717-731.

13. National Institute for Public Health and Environment (2015) Dutch health care performance report 2014. National Institute for Public Health and the Environment. [Online] Available from: https://www.rivm.nl/bibliotheek/rapporten/2015-0050.pdf [Accessed 25/08/2019]. 
14. National Statistical Institute (2019) Database. [Online] Available from: https://www.nsi.bg/ [Accessed 15-20/09/2019].

15. Newey, C., Nolte, E., McKee, M. and Mossialos, E. (2004) Avoidable mortality in the enlarged European Union. Paris: Institut des Sciences de la Santé.

16. Nolte, E. and McKee, M. (2008) Measuring the health of nations: Updating an earlier analysis. Health Affairs. 27 (1). pp. 58-71.

17. Rohova, M. (2017) Regional imbalances in distribution of Bulgarian health professionals. Journal of IMAB. 23 (1). pp. 1427-31.

18. Rutstein, D., Berenberg, W., Chalmers, T.C., Child, C.G., Fishman, A.P. and Perrin, E.B. (1976) Measuring the quality of medical care. A clinical method. New England Journal of Medicine. 294 (11). pp. 582-8.

19. Tobias, M. and Yeh, L. (2009) How much does health care contribute to health gain and to health inequality? Trends in amenable mortality in New Zealand 1981-2004. Australian and New Zealand Journal of Public Health. 33. pp. 70-8.

20. Wagstaff, A., Flores, G., Hsu, J., Smitz, M.F., Chepynoga, K., Buisman, L.R., et al. (2018) Progress on catastrophic health spending in 133 countries: a retrospective observational study. Lancet Global Health. 2018. 6. pp. e169-79.

21. Whitehead, M. (1991) The concepts and principles of equity and health. Health Promotion International. 6 (3). pp. 217-28.

22. World Health Organisation. Regional Office for Europe (2010) Portugal health system performance assessment. Copenhagen: WHO Regional Office for Europe. [Online] Available from: http://www.euro.who.int/_data/assets/pdf_file/0006/131766/E94518.pdf?ua=1 [Accessed 25/08/2019].

23. World Health Organisation (2001) Report on WHO technical consultation on fairness of financial contribution. Geneva: WHO.

24. World Health Organisation (2016) World Health Statistics 2016. Monitoring health for the sustainable development goals. Geneva: WHO.

25. Wyszewianski, L. (1986) Financially catastrophic and high-cost cases: definitions, distinctions, and their implication for policy formulation. Inquiry. 23 (4). pp. 382-394.

26. Xu, K., Evans, D.B., Kawabata, K., Zeramdini, R., Klavus, J. and Murray, C.J.L. (2003) Household catastrophic health expenditure: a multicountry analysis. Lancet. 362. pp. 111-17. 